\title{
Rapid Absorption and Local Redistribution of Progesterone after Vaginal Application in Gilts
}

\author{
By N. Einer-Jensen, J. Kotwica, T. Krzymowski, S. Stefanczyk-Krzymowska and T. Kaminski
}

Department of Physiology, Odense University, Denmark, Department of Animal Physiology, University of Agriculture and Technology, Olsztyn, and Division of Reproductive Endocrinology and Physiology, Centre for Agrotechnology and Veterinary Sciences of Polish Academy of Sciences, Olsztyn, Poland.

\begin{abstract}
Einer-Jensen, N., J. Kotwica, T. Krzymowski, S. Stefanczyk-Krzymowska and T. Kaminski: Rapid absorption and local redistribution of progesterone after vaginal application in gilts. Acta vet. scand. 1993, 34, 1-7. - Catheters were implanted in 6 anaesthetized gilts ( 3 animals in the follicular phase, 3 in the luteal phase) into a carotid artery and into the utero-ovarian vein and uterine artery on both sides. The uterine lumina were closed by a suture. Further, a catheter was inserted into the vagina after which the animals were allowed to recover. Tritiated progesterone was infused into vagina the following day during a $2 \mathrm{~min}$ period and simultaneous blood samples collected from the 5 catheters every $10 \mathrm{~min}$ for $2 \mathrm{~h}$ after which the animals were sacrificed. Tissue samples were obtained from the genital organs.

The results showed a rapid absorption of progesterone from the vaginal lumen and a marked redistribution to the genital organs. The increased level of radioactivity in the plasma samples collected from the uterine arteries compared to the simultaneous samples from the carotid artery in 2 of the 3 animals in the luteal phase indicates the existence of a local redistribution system.
\end{abstract}

vaginal infusion; progesterone; vaginal absorption; counter current transfer; local redistribution; ovary; uterus; mesometrium.

\section{Introduction}

Anatomical structures suggestive for the local transfer of substances between the utero-ovarian vein and the ipsilateral ovarian artery have been described for some (e.g. cow, sheep, pig) but not all (e.g. horse) farm animals (see Ginther 1976). Concurrently, several types of substances, including prostaglandins and peptideand steroid hormones, have been found to be transferred between vessels in the ovarian adnex in laboratory animals, sheep, swine, cow and man (see Einer-Jensen 1988, Einer-Jensen et al. 1989, Krzymowski et al. 1990).

The transfer of substances was originally shown to take place from vein blood to ovarian arte- rial blood in the closely connected vessels in the ovarian adnexa but later, transfer was also suggested to take place from the lymph to the ovarian arterial blood (Kotwica 1980). Lymph is an important carrier of steroid hormones (Magness \& Ford 1982, 1983); experimental evidence for transfer from lymph to arterial blood has been found by 2 groups (Kotwica et al. 1983, Heap et al. 1985, Krzymowski et al. 1987).

In the swine, lymph originating from the mucous membrane and muscles in the cranial part of vagina are collected by small lymph vessels. The small vessels join to form 2 or 3 bigger vessels in each side passing through plica urogenitalis. 
Table 1. Radioactivity in plasma $(\mathrm{cpm} / \mathrm{ml})$ after infusion of tritiated progesterone into the vagina in 2 groups of 3 gilts.

\begin{tabular}{|c|c|c|c|c|c|c|c|c|c|}
\hline \multirow[b]{2}{*}{ Min } & \multicolumn{3}{|c|}{ Carotid artery ${ }^{1)}$} & \multicolumn{3}{|c|}{ Uterine artery $^{2)}$} & \multicolumn{3}{|c|}{ Utero-ovarian vein ${ }^{3)}$} \\
\hline & Mean & Std & $\overline{\mathbf{N}}$ & $\overline{\text { Mean }}$ & Std & $\overline{\mathrm{N}}$ & $\overline{\text { Mean }}$ & Std & $\overline{\mathrm{N}}$ \\
\hline \multicolumn{10}{|c|}{ Luteal phase } \\
\hline 0 & 0 & 0 & 2 & 0 & 0 & 3 & 0 & 0 & 6 \\
\hline 10 & 0 & 0 & 2 & 22 & 23 & 3 & 61 & 44 & 6 \\
\hline 20 & 6 & 3 & 2 & 23 & 10 & 3 & 51 & 23 & 6 \\
\hline 30 & 10 & 3 & 2 & 11 & 10 & 3 & 40 & 22 & 6 \\
\hline 40 & 6 & 0 & 2 & 25 & 19 & 3 & 32 & 23 & 6 \\
\hline 50 & 6 & 0 & 2 & 7 & 8 & 3 & 21 & 19 & 6 \\
\hline 60 & 7 & 2 & 2 & 18 & 10 & 3 & 38 & 26 & 6 \\
\hline 70 & 8 & 0 & 2 & 10 & 11 & 3 & 26 & 17 & 6 \\
\hline 80 & 8 & 4 & 2 & 11 & 12 & 3 & 21 & 22 & 6 \\
\hline 90 & 10 & 4 & 2 & 23 & 13 & 3 & 36 & 29 & 6 \\
\hline 100 & 6 & 2 & 2 & 21 & 18 & 3 & 53 & 77 & 6 \\
\hline 110 & 5 & 3 & 2 & 17 & 8 & 2 & 23 & 27 & 5 \\
\hline 120 & 11 & 4 & 2 & 15 & 12 & 2 & 48 & 47 & 6 \\
\hline Follicular & \multicolumn{3}{|c|}{ Carotid artery } & \multicolumn{3}{|c|}{ Uterine artery $^{3)}$} & \multicolumn{3}{|c|}{ Utero-ovarian vein } \\
\hline 0 & 0 & 0 & 3 & 0 & 0 & 4 & 0 & 0 & 6 \\
\hline 10 & 8 & 7 & 3 & 18 & 27 & 4 & 16 & 13 & 6 \\
\hline 20 & 9 & 8 & 3 & 35 & 37 & 3 & 16 & 11 & 5 \\
\hline 30 & 10 & 9 & 3 & 70 & 95 & 3 & 18 & 13 & 5 \\
\hline 40 & 19 & 17 & 3 & 15 & 4 & 3 & 17 & 15 & 6 \\
\hline 50 & 15 & 4 & 3 & 14 & 5 & 3 & 14 & 12 & 6 \\
\hline 60 & 16 & 15 & 3 & 15 & 4 & 4 & 13 & 8 & 6 \\
\hline 70 & 18 & 3 & 3 & 29 & 24 & 4 & 15 & 9 & 6 \\
\hline 80 & 25 & 19 & 3 & 16 & 6 & 4 & 14 & 8 & 6 \\
\hline 90 & 14 & 4 & 3 & 16 & 0 & 2 & 22 & 11 & 5 \\
\hline 100 & 20 & 8 & 3 & 18 & 4 & 2 & 26 & 7 & 4 \\
\hline 110 & 14 & 2 & 3 & 47 & 56 & 4 & 24 & 15 & 5 \\
\hline 120 & 39 & 22 & 3 & 19 & 13 & 4 & 22 & 14 & 3 \\
\hline
\end{tabular}

1) No samples from one catheter

2) No samples from 3 catheters, separate animals

3) No samples from 2 catheters, separate animals

The vessels unite with lymph vessels draining the caudal part of the uterus and end in either the hypogastric, medial iliac or para-aortic lymph glands. The lymph vessels from the most caudal part of vagina take a different direction to the superficial inguinal lymph glands (Baum \& Grau 1938). A similar lymph drainage has been found in the cow (Jelinek \& Kacer 1973, Baum 1912).
Vaginal administration of drugs has been used for centuries. Rather little is, however, known about the speed or route (lymph or venous blood) by which the removal of the hormones takes place. In women, a significant association between steroid absorption kinetics and the condition of the vaginal mucosa may exist: significantly higher absorption from the vagina of estradiol-17ß and progesterone was found in 5 


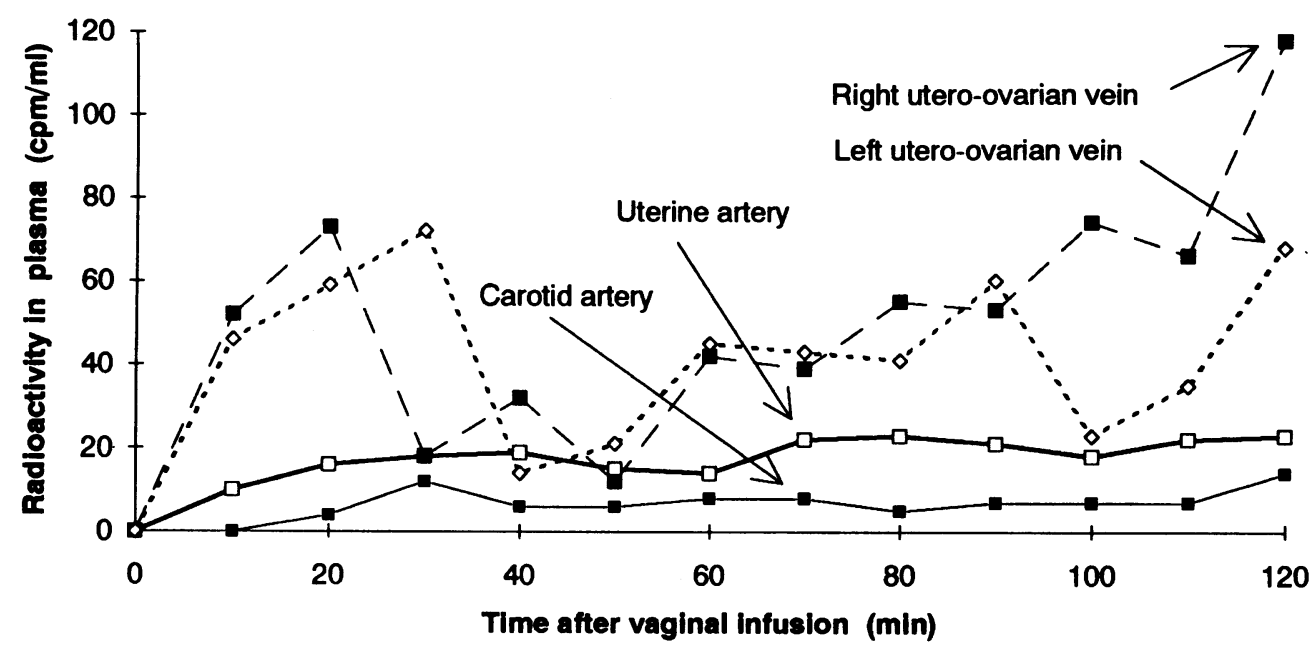

Figure 1. Radioactivity in plasma obtained from the carotid artery, the right uterine artery and the left and right utero-ovarian veins, respectively, in a gilt in the luteal phase after intravaginal application of ${ }^{3} \mathrm{H}$-progesterone.

postmenopausal women with low pre-treatment serum steroid levels and an atrophic vaginal mucosa than in 5 similar women with normal steroid levels (Pschera et al. 1989).

The present study was performed in order to investigate the resorptive capacity of vagina, e.g. the speed and completeness by which infused progesterone was removed, and in order to obtain indications of a possible local transfer of progesterone from vagina to the other genital organs.

\section{Methods}

Six non-pregnant, sexually mature gilts of Polish Large White Breed (weight $100-110 \mathrm{~kg}$, age 7 -8 months) were used. Three of the animals were in the follicular phase, the other 3 were in the luteal phase; this was checked during the surgery by visual inspection of the ovaries. Intramuscular premedication was given consisting of atropine $(0.05 \mathrm{mg} / \mathrm{kg}$ body weight $)$ and $\mathrm{N}$ (3.3.dimethyl amino propyl)-3-propionyl pheno- thiasin-phosphate (Combelen, Bayer, Germany, $10 \mathrm{mg} /$ gilt). General anaesthesia was induced by intravenous injection of pentabarbital (Vetbutal, Biovet, Poland, approx. $1.2 \mathrm{mg} / \mathrm{kg}$ body weight) and supplementary doses were given during surgery according to effects.

Laparatomy was performed under sterile conditions. Catheters were inserted into a branch of the uterine artery (catheter measurements: ID $0.8 \mathrm{~mm}$, OD $1.1 \mathrm{~mm}$ ) in the area of the broad ligament, approx. $10 \mathrm{~cm}$ from the uterine horn and into a small uterine vein (ID 1.0, OD $1.4 \mathrm{~mm}$ ) in the mesometrium on each side. The tips of the arterial catheters were pointing towards the flow and occluding the lumen of the small branch. The tips of the venous catheters were positioned in the utero-ovarian vein on both sides. A fifth catheter (ID $1.6 \mathrm{~mm}$, OD 2.2 $\mathrm{mm}$ ) was inserted into a carotid artery. All 5 catheters were filled with heparin-saline (100 IU/ml), led subcutaneously to the back of the animal and fixed to the skin by tape. A circular suture was tied through the myometrium just proximal to 
Table 2. Within animal differences in radioactivity $(\mathrm{cpm} / \mathrm{ml})$ in plasma samples between genital vessels after infusion of tritiated progesterone into the vagina

\begin{tabular}{|c|c|c|c|c|c|c|c|}
\hline \multirow[b]{2}{*}{ Phase } & \multirow{2}{*}{$\begin{array}{l}\text { Gilt } \\
\#\end{array}$} & \multicolumn{6}{|c|}{ Mean and $95 \%$ confidence interval } \\
\hline & & \multicolumn{2}{|c|}{ Uterine artery-carotid artery } & \multicolumn{2}{|c|}{ Uterine vein-carotid artery } & \multicolumn{2}{|c|}{ Uterine vein-uterine artery } \\
\hline \multicolumn{8}{|c|}{ Luteal phase } \\
\hline & 212 & & & & & $32.5(17.9-47.0)$ & ** \\
\hline & 213 & $11.4(9.1-13.8)$ & ** & $41.4(29.7-53.0)$ & $* *$ & $30.0(18.2-41,7)$ & ** \\
\hline & 214 & $3.3(0.5-6.2)$ & * & $6.5(0.6-12.4)$ & $*$ & $3.2(-0.3-7.1)$ & \\
\hline \multicolumn{8}{|c|}{ Follicular phase } \\
\hline & 208 & $45.4(-15.4-106$ & & $-3.9(-7.2-4.7)$ & & $-53.8(-111.0-3.4)$ & \\
\hline & 209 & $0.2(-7.6-8.1)$ & & $-0.6(-9.6-8.4)$ & & $-2.8(-7.2-1.7)$ & \\
\hline & 224 & $1.6(-4.0-7.2)$ & & $8.7(5.4-12.1)$ & * & $6.5(-0.1-13.0)$ & \\
\hline
\end{tabular}

Probability: $* \mathrm{p}<0.05, * * \mathrm{p}<0.01$

cervix in order to occlude both the uterine lumina, but avoiding the subserosal lymph vessels. The abdominal incision was closed. A sixth catheter (ID $1.0 \mathrm{~mm}$, OD $1.4 \mathrm{~mm}$ ) was inserted into the vaginal lumen. The tip was positioned in the cranial part of vagina and the catheter fixed, after which the animal was allowed to recover.

The conscious animal, kept in a small pen, was used for the experiment $24 \mathrm{~h}$ after the start of the surgery. 10000 IU heparin was given through an ear vein and $0.5 \mathrm{ml}$ saline containing ${ }^{3} \mathrm{H}$-progesterone (app. $710^{7} \mathrm{cpm} / \mathrm{ml}$, spec. act. $3.03 \mathrm{TBq} / \mathrm{mmol},\left(1,2,6,7-{ }^{3} \mathrm{H}\right)$ progesterone, Amersham, U.K.) was infused during a $2 \mathrm{~min}$ period

through the vaginal catheter. Simultaneous blood samples were obtained from the 5 catheters before and every $10 \mathrm{~min}$ after the infusion for $120 \mathrm{~min}$. Plasma was separated and kept frozen until the radioactivity was assayed by liquid scintillation counting. A previous investigation by thin-layer chromatography analysis indicated that $64-69 \%$ of the radioactivity in plasma corresponded to the tritiated steroid hormone infused (Krzymowski, et al. 1981).

The animal was sacrificed after the last collection by an overdose of barbiturate and the genital organs removed for further dissection. Tissue samples of approx. $100 \mathrm{mg}$ were removed, weighed on a torsion balance and the radioactivity counted by liquid scintillation techniques. The following tissue samples (numbers in bracket) were collected from each side: ovarian tissue (2), myometrium (3), endometrium (3), mesovarium (1), mesometrium (3). Three samples of follicular fluid $(200 \mu \mathrm{l})$ were collected from each side if the animal was in the follicular phase. Likewise, 3 samples of corpus luteum samples were collected from each side, if this tissue was present. Two samples from the cervix and 2 from the vagina were also assayed. The tissue samples were processed by $0.5 \mathrm{ml}$ "Tissue Sölubilizer" (BTS, Beckman Instruments, USA) and $10 \mathrm{ml}$ "Ready Organic Cocktail" (ROC, Beckman Instruments, USA), the plasma samples with the "Ready Organic Cocktail" only. Radioactivity in each sample was counted for 10 min in a liquid scintillation counter (LS-7500, Beckman Instruments, USA) with an efficiency for tritium of $56 \%$. Pre-infusion background values for plasma have been subtracted in the results stated below. 
Table 3. Radioactivity in tissue samples ( $\mathrm{cpm} / \mathrm{g}) 2 \mathrm{~h}$ after infusion of tritiated progesterone into the vagina of 2 groups of 3 gilts.

\begin{tabular}{lccccccc}
\hline & \multicolumn{3}{c}{ Luteal phase } & & \multicolumn{3}{c}{ Follicular phase } \\
\cline { 2 - 4 } \cline { 6 - 7 } & Mean & Std & N & & Mean & Std & N \\
\hline Corpus luteum & 911 & 616 & 18 & & - & - & - \\
Follicular fluid & - & - & - & & 1056 & 1238 & 16 \\
"Rest" of ovary & 439 & 454 & 12 & & 231 & 154 & 12 \\
Myometrium & 717 & 454 & 18 & & 175 & 154 & 18 \\
Endometrium & 526 & 234 & 18 & & 196 & 216 & 18 \\
Mesovarium & 598 & 350 & 6 & & 226 & 202 & 6 \\
Mesometrium & 740 & 606 & 17 & & 209 & 168 & 18 \\
Cervix & 483 & 375 & 6 & 334 & 344 & 6 \\
Vagina & 597 & 303 & 6 & 427 & 475 & 6 \\
\hline
\end{tabular}

\section{Results}

Radioactivity was in some instances increased already in the first plasma samples taken $10 \mathrm{~min}$ after the start of the infusion and could be seen throughout the 120 min sampling period (Table 1). The results are based on 24 series of samples out of the 30 possible; in 6 cases no samples could be obtained from a catheter. In 5 series, 1 to 5 samples were missing. The pattern of response appeared to differ between the animals in the luteal phase and the animals in the follicular phase and the results will therefore be treated separately.

The radioactivity in plasma samples obtained from the uterine artery was significantly higher $(\mathrm{p}<0.01$ and $\mathrm{p}<0.05$, respectively) than the radioactivity in the parallel plasma samples obtained from the carotid artery in 2 out of the 3 gilts in the luteal phase (see Fig 1 for an excample). The average within animal difference at each sampling time was $11.4(9.1-13.8) \mathrm{cpm} / \mathrm{ml}$ (mean and 95\% confidence interval) and 3.3 (0.56.2) $\mathrm{cpm} / \mathrm{ml}$. No samples could be obtained from the carotid artery in the third animal.

A significant increase in radioactivity was also observed in 5 out of 6 series in plasma samples obtained from the uterine veins compared to parallel plasma samples obtained from the carotid and/or uterine artery in the animals in the luteal phase (Table 2, Fig. 1).

No differences were found in any of the 3 animals in the follicular phase between the uterine vein samples and the uterine arterial samples. A significant difference between the uterine vein samples and the carotid artery was found in 1 case (animal no. 24, Table 2).

All tissue samples obtained $2 \mathrm{~h}$ after the vaginal instillation contained radioactivity (Table 3 ). It was present not only in the genital organs but also in the mesometrium and mesovarium. The highest content was observed in corpora lutea tissue and follicular fluid, respectively. The radioactivity in the vaginal tissue was similar to that in the other tissue samples $2 \mathrm{~h}$ after the infusion. No difference was found in the distribution pattern in comparable tissue samples between animals in the luteal and follicular phases.

\section{Discussion}

Vaginal infusion of progesterone leads to a rapid absorption and redistribution of the radioactivity and presumably the hormone, as shown 
by the appearance in plasma after $10 \mathrm{~min}$ and by the low residual concentration in the vaginal tissue after $2 \mathrm{~h}$. Removal of the hormone must be based on transport in lymph and/or blood, as intraluminal diffusion was prevented by ligation of the uterine lumina before the infusion. The results obtained from similar experiments with the uterus indicate that both ways of transport must be considered (Koziorowski et al. 1988). The absorption was similar in the luteal and follicular phases as judged from the similarity in radioactivity found in the genital organs.

The increase in radioactivity in the utero-ovarian vein plasma compared to the other plasma samples from the animals in the luteal phase shows that some of the radioactivity removed from the vagina probably is removed by the uterine vein blood, even if these veins, based on anatomical evidence, may not be the prime recipient of blood from the vagina. Part of the increased radioactivity found in the uterine veins may also originate from venous drainage of uterine tissue from which counter current transfer of the radioactive hormone resulted in a relative increase in the tissue content.

In general, one would expect the same amount of radioactivity in plasma obtained from any artery in the body due to mixing of blood in the heart chambers. There are, however, strong indications from the animals in the luteal phase of a local increase of radioactivity in uterine arterial plasma when compared with simultaneous carotid artery samples. This indicates that some of the labelled progesterone appearing in the uterine vein blood or the vaginal lymph may be transferred to plasma in the uterine artery through the walls of the vessels. The mechanism has, to the knowledge of the authors, not been shown previously. It is parallel to the transfer found from uterine lymph and vein blood to uterine arterial plasma (Krzymowski et al. 1986). This transfer has also been found after intra-uterine application (Koziorowski et al. 1988).
The transfer was found to be significant from 2 out of 3 of the animals in the luteal phase, carotid plasma samples were not obtained from the last animal. Only 1 out of 3 animals in the follicular phase showed indications of a transfer during part of the $2 \mathrm{~h}$ period. The transfer may thus be cycle dependent, as has been found with respect to steroid transfer from ovarian vein blood to tubal arterial blood (Krzymowski et al. 1982, Hunter et al. 1983).

\section{Acknowledgement}

We are grateful to Dr T.M.M. Farley for advice regarding the statistical analysis and to Dr. G.M.H. Waites for valuable discussions.

\section{References}

Baum H: Das Lymphgefäßsystem des Rindes. (The lymphatic system in cattle). August Hirschwald, Berlin, 1912.

Baum H, Grau H: Das Lymphgefäßsystem des Schweines. (The lymphatic system in swine). Paul Parey, Berlin, 1938.

Einer-Jensen $N$ : Counter current transfer in the ovarian pedicle and its physiological implications. Oxford Review of Reprod. Biol. 1988, 10, 348-381.

Einer-Jensen N, McCracken JA, Schramm W, Bendz $A$ : Counter current transfer in the female adnexa. Acta Physiol. Pol. 1989, 40, 3-11.

Ginther OJ: Comparative anatomy of uteroovarian vasculature. Vet. Scope 1976, 20, 1-17.

Heap RB, Fleet IR, Hamon M: Prostaglandin $\mathrm{F}_{2 \alpha}$ is transferred from the uterus to the ovary in sheep by lymphatic and blood vascular pathways. J. Reprod. Fert. 1985, 74, 645-656.

Hunter RHF, Cook B, Poyser NL: Regulation of oviduct function in pigs by local transfer of ovarian steroids and prostaglandins: A mechanism to influence sperm transport. Europ. J. Obstet. Repr. Biol. 1983, 14, 225-231.

Jelinek K, Kacer V: Die Lymphkapillaren der Portio vaginalis uteri der Kuh. (The lymphatic capillaies in Portio vaginalis uteris in the cow). Anat. Anz. 1973, 133, 431-440.

Kotwica J: Mechanism of $\mathrm{PGF}_{2 \alpha}$ penetration from the horn of the uterus to ovaries in pigs. J. Reprod. Fert. 1980, 59, 237-241.

Kotwica J, Krzymowski T, Stefanczyk S, Koziorowski M, Czarnocki, J, Ruszczyk T: A new route of 
prostaglandin $F_{2 \alpha}$ transfer from the uterus into the ovary in swine. Anim. Reprod. Sci. 1983, 5, 303-309.

Koziorowski M, Stefanczyk-Krzymowska S, Okrasa S, Czarnocki J, Krzymowski T: Radioactive prostaglandin $\mathrm{F}_{2 \alpha}$ absorption from the uterine lumen into venous blood and its back transfer from the broad ligament vasculature during early pregnancy of the gilt. Proc. 11th Inter. Congr. Anim. Reprod. A.I. Dublin, 1988.

Krzymowski T, Kotwica J, Stefanczyk S, Debek J, Czarnocki J: Venous-arterial counter current exchange of testosterone, estradiol and progesterone in sow's ovarian vascular pedicle. Adv. Physiol. Sci. 1981, 20, 153-157.

Krzymowski T, Stefanczyk S, Koziorowski M, Czarnocki $J$, Ruszczyk T, Nowicka R: Role of mesosalpinx oviduct vasculature in the counter current transfer of steroid hormones into the ovary. Anim. Reprod. Sci. 1982, 5, 25-39.

Krzymowski T, Czarnocki J, Koziorowski M, Kotwica J, Stefanczyk-Krzymowska S: Counter current transfer of ${ }^{3} \mathrm{H}-\mathrm{PGF}_{2 \alpha}$ in the mesometrium: A possible mechanism for prevention of luteal regression. Anim. Reprod. Sci. 1986, 11, 259-272.

Krzymowski T, Kotwica J, Stefanczyk S, Czarnocki J, Koziorowski M: Prostaglandin ${ }_{\mathrm{F} 2 \alpha}$ back transfer from the mesometrium vasculature into the uterus of the gilt during early pregnancy and estrogen-induced pregnancy. Anim. Reprod. Sci. 1987, 13, 199-210.

Krzymowski T, Kotwica J, Stefanczyk-Krzymowska S: Uterine and ovarian countercurrent pathways in the control of ovarian function in the pig. $J$. Reprod. Fert. Ster. 1990, Suppl., 40, 179-191.

Magness RP, Ford SP: Steroid concentrations in uterine lymph and uterine arterial plasma of gilts during the estrus cycle and early pregnancy. Biol. Reprod. 1982, 27, 871-877.

Magness RP, Ford SP: Estrone, estradiol-17ß and progesterone concentrations in uterine lymph and systemic blood throughout the porcine estrus cycle. J. Anim. Sci. 1983, 57, 449-455.

Pschera H, Hjerpe A, Carlström K: Influence of the maturity of the vaginal epithelium upon the absorption of vaginally administered estradiol-17- $\beta$ and progesterone in postmenopausal women. Gynocol. Obstet. Invest. 1989, 27, 204-7.

\section{Sammendrag \\ Hurtig optagelse og lokal refordeling af progesteron efter vaginal tilførsel til gylte}

Katetre blev indsat $i$ carotis, utero-ovarie venen og uterus arterien på 6 bedøvede gylte. Næste dag blev parallelle blodprøver udtaget gennem katetrene før og hvert 10. min efter deponering af tritieret progesteron i vagina. Dyrene blev aflivet efter $2 \mathrm{t}$, hvorefter vævsprøver blev udtaget fra genitalorganerne.

En hurtig øgning af mængden af radioaktivitet kunne påvises i plasmaprøverne. Dette tyder på, at progesteron blev optaget hurtigt fra vagina. Mængden af radioaktivitet var $h \varnothing j$ jere i prøver fra uterus arterien end i prøver fra carotis i 2 af 3 dyr i lutealfase, men ikke i de tilsvarende prøver fra 3 dyr i follikelfase. Dette tyder på, at redistribution af progesteron kan ske lokalt mellem vagina's og uterus' blod- og lymfekar, og at udvekslingens effektivitet har sammenhæng med den $\emptyset$ strale cyklus. Påvisning af radioaktivitet i vævsprøverne viser, at progesteron deponeret $i$ vagina kan forventes at nå genitalorganerne.

(Received August 26, 1992; accepted November 17, 1992).

Reprints may be requested from: N. Einer-Jensen, Av. de la Foretaille 8 D, CH-1292 Chambésy, Switzerland. 
